\title{
Impact of City Social Responsibility and Marketing Strategy on City Image and People's Perception
}

\author{
Shwu-Ing $\mathrm{Wu}^{1} \& \mathrm{Ni}-$ Wei Liou ${ }^{1}$ \\ ${ }^{1}$ Department of Business Administration, National Chin-Yi University of Technology, Taiwan, Republic of \\ China \\ Corresponding: Shwu-Ing Wu, Department of Business Administration, National Chin-Yi University of \\ Technology, No.57, Section 2, Zhongshan Road, Taiping, Taichung, Taiwan 411, R.O.C. E-mail: \\ wusi@ncut.edu.tw
}

Received: August 13, 2015

Accepted: September 8, 2015 Online Published: November 30, 2015

doi:10.5539/jms.v5n4p30

URL: http://dx.doi.org/10.5539/jms.v5n4p30

\begin{abstract}
In recent years, the issue of Corporate Social Responsibility (below referred to as "CSR") has received considerable attention. The term CSR is usually associated with enterprises, while the social responsibility of cities is rarely explored. However, cities resemble non-profit enterprises and whether or not they fulfill their social responsibility has a significant impact on future development. This study therefore conducts a literature analysis and empirical research to investigate the impact of city social responsibility and city marketing strategies on the city image and perceptions of the general public. The research object of this study is Taichung City in Taiwan. A survey was conducted and 548 valid questionnaires were collected from non-local residents. After a group model comparison of two groups divided by high or low frequency of trips to Taichung it was discovered that: (1) Both groups exhibit a significant positive correlation between the fulfillment of city social responsibility and people's trust. (2) The high frequency group shows a significant positive correlation between the fulfillment of city social responsibility and city image, while the low frequency group shows no such relationship and a significant difference exists between the two groups. (3) The low frequency group shows a significant negative correlation between the implementation of marketing strategies by the city and public trust. (4) Both groups exhibit a significant positive correlation between the implementation of marketing strategies by the city and city image and the correlation intensity is considerably higher for the low frequency group. (5) Both groups show a significant positive correlation between the implementation of marketing strategies by the city and people's intention. (6) Both groups exhibit a significant positive correlation between city image and people's trust. (7) The high frequency group shows a significant positive correlation between people's trust and people's intention, while the low frequency group shows no such relationship and a significant difference exists between the two groups. The results of this study clearly indicate that the behavior patterns of groups with different travel frequencies are somewhat distinct. City administrators should therefore pay special attention to the planning of city CSR and city marketing strategies to be able to attract visits, investments, and settlement by target groups.
\end{abstract}

Keywords: city social responsibility, city marketing strategy, city image, people's intention

\section{Introduction}

In recent years, CSR has turned into an issue attracting wide attention. The term social responsibility is usually associated with enterprises. According to the World Business Council for Sustainable Development (WBCSD), CSR is defined as: "A commitment of enterprises to continued compliance with ethical norms, contributions to economic development, as well as improvement of the life quality of staff members and their families, local communities, and the whole society. "This clearly shows that enterprises and society are closely intertwined. From the perspective of individual cities, social responsibility is even more important due to the fact that urban policies have a considerable impact on society, the market economy, and the environment.

In addition to the shouldering of social responsibility, marketing power is required to increase the awareness and liking for the city among the general public. Due to the fierce competition generated by global liberalization, traditional marketing activities are no longer able to satisfy urban development goals and the needs of citizens. To maximize the effect of city marketing and promotion it is necessary to constantly explore new marketing methods. Cities can also enhance their competitiveness through innovative marketing which is an important tool 
for urban operations. Urban marketing generates positive effects including economic development, establishment of local characteristics, infrastructure construction, and attraction of tourists and investments.

CSR also affects the trust of consumers in the enterprise. If the enterprise meets or transcends the social responsibility expected by consumers, its brand image and sense of trust in the enterprise on the part of consumers are enhanced, which in turn increases the willingness to consume. The same observations apply to cities.

Only a very small number of studies explore the impact and effects of social responsibility and city marketing from the perspective of cities. This study therefore focuses on Taichung City in Taiwan to analyze the impact of the social responsibility and marketing strategies of cities on city image and people's trust and intention. In addition to the establishment of a relationship model it was examined whether groups with different travel frequencies exhibit significant differences in the intensity of correlations between the dimensions. The goal is to provide city administrators with valuable information. The research objects of this study are non-Taichung residents aged 15 or above and the research objective is an in-depth analysis of the impact of city social responsibility and marketing strategies on cities.

\section{Literature review}

\subsection{City Social Responsibility}

The term social responsibility is usually associated with enterprises. Carroll (1991) has proposed the concept of a four-layer CSR pyramid. Economic responsibilities form the bottom layer of the pyramid followed by legal responsibilities, ethical responsibilities, and philanthropic responsibilities. This theory may also be applied to urban operations. Administrators and decision-makers have the duty to fulfill their social responsibility, the administrative heads of cities must therefore adopt measures to protect and promote social welfare (Davis \& Blomstrom, 1975). Sexty (2011) argues that corporate operations not only involve economic and legal obligations but also an equal emphasis on economic, social, and environmental responsibilities as well as the satisfaction of the expectations of shareholders and stakeholders. Cities, on the other hand, should safeguard the interests and meet the expectations of all citizens. To sum up, this study employs the four dimensions of social responsibility proposed by Carroll (1991) to measure city social responsibility.

\subsection{City Marketing Strategy}

Kotler, Haider and Rein (1993) define city marketing as active marketing by regional market-oriented enterprises for the purpose of developing attractive products of their cities to achieve the goals of urban development or in other words a strategy orientation based on regional advantages and disadvantages, opportunities, and threats. Armstrong \& Kotler (2000) classify city marketing strategies into four categories: 1 Brand marketing (creation of a long-term positive image); 2 Attraction marketing (satisfaction and attraction of residents and visitors through attractive places of interest); 3 Infrastructure marketing (improvement of public infrastructure installations); 4 People marketing (Introduction by citizens to attract a large number of visitors). This study measures city marketing strategy based on the four marketing strategy categories proposed by Armstrong \& Kotler (2000).

\subsection{City Image}

City image which has a wide impact is one of the methods to give people a better understanding of cities. Many cities are therefore committed to creating a positive image to raise the awareness and interest of people in these cities. Hattori-Keijiro (1984) points out that city image is composed of four main elements: 1 Local customs and conditions; 2 Historical impressions; 3 Expression of modernism; 4 Urban philosophy. Luque-Martinez, Barrio-Garcia, Ibanez-Zapata \& Molina (2007), on the other hand, list the following elements: 1 Attractive urban architecture; 2 Infrastructure; 3 Historical heritage; 4 Environment; 5 Social problems; 6 Culture; 7 Corporate culture and innovation; 8 Economy and commercial trade; 9Range of public facilities; 10 University education; 11 International planning; 12 Self-awareness of the general public; and 13 City image and satisfaction. This study summarizes the concepts proposed by the abovementioned scholars and selects the following dimensions to measure city image: Landscape construction, infrastructure, local customs and conditions, and history \& culture.

\subsection{People's Trust}

Trust is based on a long-term relationship (Sirdeshmukh, Singh, \& Sabol, 2002). Gefen (2002) believes that trust is based on past experiences and confidence that the behavior of the other party meets the own expectations. Ranaweera \& Prabhu (2003) argue that trust connotes a belief of one party in the trustworthiness of another and implies a high level of integrity and confidence. Ganesan (1994) divides trust into two dimensions: Reliability 
and goodwill. The former refers to the ability and intention to honor commitments on the part of trading counterparties, while the latter denotes a genuine concern for the other party and a willingness to sacrifice own interests to safeguard the interests of the other party. This study therefore measures people's trust through the dimensions of reliability and goodwill.

\subsection{People's Intention}

Travel intention is a readiness-to-buy concept (Pike \& Ryan, 2004) which refers to the possibility and willingness of tourists to purchase tourism products. Boulding et al. (1993), Cronin et al. (2000) suggest the following dimensions for the measurement of consumer behavioral intention: Repurchase intention, referral, and willingness to make greater efforts. The concept of people's intention may provide a greater understanding of the attraction of cities. For instance, Gronhold, Martensen \& Kristensen (2000) propose four measurement dimensions for the intention of tourists to visit a certain area: 1 Revisit intention; 2 Recommendation intention; 3 Price tolerance; 4 Secondary behavior. This study therefore measures the intention of the general public to accept a certain city through the concepts of visit intention, revisit intention, residence intention, and recommendation intention.

\section{Research Hypotheses}

\subsection{Relationship between City Social Responsibility and Peoples' Trust}

Fulfillment of social responsibility by enterprises enhances their image in society and gains the trust and support of more customers (Moussavi \& Evans, 1986). Sen \& Bhattacharya (2006) point out that the implementation of social responsibility on the part of enterprises generates positive stakeholder attitudes and investment intentions as well as purchases and acceptance of the behavior of the enterprise. By the same token, fulfillment of social responsibility by cities engenders greater trust by the general public. This study therefore postulates that the implementation of social responsibility by cities is positively correlated with people's trust, as following:

\section{H1: Fulfillment of social responsibility by cities has significant positive influence on people's trust.}

\subsection{Relationship between City Social Responsibility and City Image}

When an enterprise fulfills its social responsibility, a positive effect on its corporate image is generated and the maintenance of the company's competitive edge is facilitated (Zairi \& Peters, 2002). Brammerand \& Millington (2005) point out that enterprises which carry out philanthropic activities are indeed able to enhance their corporate reputation as well as their corporate image. Enterprises employ sponsorship activities to accumulate more assets, which in turn leads to brand image differentiation and brand uniqueness (Chien et al., 2011). It can therefore be assumed that the implementation of social responsibility by cities has a positive effect on city image, as following:

H2: Fulfillment of social responsibility by cities has significant positive influence on city image.

\subsection{Relationship between City Social Responsibility and Peoples'Intention}

CSR activities have a direct or indirect impact on consumer purchase intentions (Sen \& Bhattacharya, 2001). Lichtenstein et al. (2004) found that enterprises can improve their rating and thereby stimulate consumer purchase behavior through the implementation of social responsibility. As far as consumers in ethnic Chinese areas are concerned, the positive image generated by the high popularity through the implementation of CSR leads to a higher purchase intention for products on the part of consumers (Tian, Wang, \& Yang, 2011). It may therefore be hypothesized that the acceptance of the general public is enhanced through the fulfillment of social responsibility by cities, as following:

H3: Fulfillment of social responsibility by cities has significant positive influence on people's intention.

\subsection{Relationship between City Marketing Strategy and Peoples' Trust}

City marketing strategies attempt to optimize cities based on mid- and long-term goals and increase their potential competitiveness as well as stimulate their internal performance and enhance the trust of people (Krantz \& Schatzl, 1997). Stable long-term relationships may be established through relationship marketing and individual travel. Commitment and trust are generated because trust has a direct impact on the maintenance of relationships (Belen et al., 2001; Chaudhuri \& Holbrook, 2001; Hennig-Thurau \& Klee, 1997). It can therefore be postulated that city marketing strategies have a significant positive effect on people's trust (Morgan \& Hunt, 1994), as following:

H4: City marketing strategy has significant positive influence on people's trust. 


\subsection{Relationship between City Marketing Strategy and City Image}

Cities can create urban brands through city marketing strategies and establish city images to achieve a promotional effect (Murphy, Benckendorff, \& Moscardo, 2007). City marketing resembles that of a non-profit seeking enterprise and aims to enhance urban competitiveness, improve the city image, increase residential welfare, and attract investments. City marketing is therefore also viewed as social marketing (Paddison, 1993). City image can be established through city marketing which has turned into an indispensable link of modern urban competitiveness (Paddison, 1993). Cities can adopt an excellent marketing mix to establish and maintain its image and attract and retain the attention of the general public. Based on the above observations the following hypothesis is proposed:

\section{H5: City marketing strategy has significant positive influence on city image.}

\subsection{Relationship between City Marketing Strategy and Peoples' Intention}

Peter \& Weiermair (2000) point out that attraction is usually man-made. Tourists can be successfully attracted through corresponding marketing methods and innovation. Burnett \& Moriarty (1998) argue that effectively integrated marketing strategies can increase the purchase intention of consumers. Schmitt (1999) stated that environmental experiences and stimuli can generate a positive impact, which in turn increases people's intention. City marketing can therefore also increase the willingness of the general public to accept cities. Based on the above observations the following hypothesis is put forward:

\section{H6: City marketing strategy has significant positive influence on people's intention.}

\subsection{Relationship between City Image and Peoples' Trust}

Corporate image is a perception generated through the knowledge, beliefs, and feelings of people about organizations (Crosby, 1990). The moral image of an enterprise and its performance in the field of environmental concern cause customers to identify with the enterprise (Gobè, 2002). The corporate image thereby affects the generation of trust or distrust on the part of the message recipient (Smeltzer, 1997). Consumers usually use brand image as an external cue for the evaluation of product quality. This explains the inseparable connection between brand image and consumer trust (Richardson et al., 1994). As far as city image is concerned, a high city image increases the sense of trust of the general public. The following hypothesis is proposed based on the above observations:

\section{H7: City image has significant positive influence on people's trust.}

\subsection{Relationship between Peoples' Trust and Peoples' Intention}

Garbarino \& Johnson (1999) believe that trust in the service provider is a main factor leading to the generation of customer satisfaction. Overall satisfaction with services, on the other hand, affects the willingness of customers for continued use. It therefore lowers the tendency to speculative behavior in trust relationships and leads to an intention to initiate long-term cooperative relationships (Ganesan, 1994) and a willingness to perpetuate mutual cooperation (Doney \& Canon, 1997). Trust has the potential to reduce uncertainty due to the fact that people know that a certain brand or item is reliable. It is also believed that reliability, safety, and honesty are key factors leading to trust (Arjun \& Morris, 2001). To sum up, it can be postulated that people's trust affects the willingness of people to visit or recommend cities. The following hypothesis is therefore proposed:

\section{H8: People's trust has significant positive influence on people's intention.}

\subsection{Relationship between City Image and Peoples' Iintention}

Bennett \& Koudelova (2001) believe that cities and regions may be viewed as products that provide enterprises with laborers, land, buildings, and infrastructure and residents with housing, welfare, cultural facilities, and a social environment. The city image is formed by these components. Roche (1994) found in his research that city image affects tourist behavior and is a key factor in the selection of destinations for visits by tourists. City image is related to perception and attitude changes toward cities and to the ability to attract investors with the goal of increasing employment opportunities and encouraging settlement. This is one of the main goals of an enhanced city image (Paddison, 1993). City image is also one of the key factors affecting travel decisions by tourists (Scharl et al., 2008). Based on the above observations, this study proposes the following hypothesis:

\section{H9: City image has significant positive influence on people's intention.}

\subsection{Comparing Groups with Different Travel Frequencies}

Kotler \& Armstrong (2005) stated that an effective segmentation of the market facilitates a better understanding of market reactions and planning of suitable marketing strategies by sales personnel. Wu \& Lin (2014) adopt 
groups with different travel frequencies as the segmentation variable. They found in their research that the correlation intensity between the dimensions of customer relationship bonds and innovative marketing on the one hand and customer satisfaction, trust, and loyalty on the other is different for groups with different travel frequencies. Wu \& Zheng (2014) also use groups with different travel frequencies as the segmentation variable. They discovered that the correlation intensity between the dimensions of tourism image and attraction on the one hand and experiential value, satisfaction, and loyalty on the other is different for groups with different travel frequencies. This clearly shows that travel frequency is an effective variable for the segmentation of tourism areas. This study aims to explore the differences between groups with different travel frequencies and therefore puts forward the following hypothesis:

H10: There are significant differences in the correlation intensity between various groups with different travel frequencies.

\section{Research Design}

\subsection{Research Framework and Research Variables}

Based on the research objectives and literature review of this study, a research framework is proposed to explore the relationship between city social responsibility, city marketing strategy, people's trust, city image, and people's intention and verify the hypotheses and conceptual models put forward in this study. The researcher also further compares the differences between segments with different travel frequencies.

The researcher collected relevant theories and studies as a foundation for the research framework and conducted a questionnaire survey to collect primary data and gain a better understanding of the opinions of the general public about city social responsibility, city marketing strategies, people's trust, city image, and people's intention. A 7-point Likert scale has been adopted for measurement purposes ranging from 1(strongly agree) to 7 (strongly disagree). Background data provided by respondents in part 6 are measured on a nominal scale.

\subsection{Pretest and Pilot}

To obtain an effective measurement tool, the researcher made revisions to the questionnaire in two stages (pretest and pilot) before distributing the formal questionnaire. The pretest process utilized a convenience sampling method to select 30 respondents who have actually visited Taichung for in-depth interviews. The results of these interviews revealed that the meaning of certain questions was unclear. Sentences were therefore rephrased and different terms were used. Upon revision of the questionnaire, another 100 respondents were selected by adopting a convenience sampling method to conduct a pretest and a reliability and validity analysis of the provided data. The questionnaire pretest revealed that the Cronbach's $\alpha$ coefficient for each measurement dimension ranges between 0.722 and 0.945 , which meets the minimum standard of a value greater than 0.7 . The item-to-total correlation coefficients all exceed a value of 0.5 , which indicates a high level of reliability for all dimensions (Nunnally, 1978; Kerlinger, 1978). The results of the factor analysis reveal that the eigenvalues for all dimensions are greater than 1 and the cumulative explained variances all exceed 0.5 . The factor loadings of all variables are greater or close to 0.5 , which in turn indicates that all dimensions have convergent validity (Kerlinger, 1978; Kaiser, 1958). This revised version of the questionnaire was therefore used for the formal survey.

\section{Results}

\subsection{Sample Structure}

The research objects of this study are non-local residents who have visited the greater Taichung area. 600 questionnaires have been distributed by adopting a convenience sampling method. After the elimination of invalid questionnaires, a total of 548 valid questionnaires remained, representing a return rate of $91.33 \%$. The sample was divided into eight sections for the analysis. As far as basic personal data are concerned, male and female respondents made up 50.7\% and 49.3\%, respectively. The age group 45-54 accounted for the largest share (21.2\%), followed by the age group 15-24 with $20.8 \%$. Most respondents reside in the southern part of Taiwan (49.1\%), while $47.1 \%$ live in northern Taiwan. $66.1 \%$ of the respondents have a university or college degree, while $20.6 \%$ are MA or PhD degree holders. Most respondents are employed in the manufacturing sector (19.2\%) followed by the service sector (16.4\%). $27.7 \%$ have an average monthly income/disposable income of 30,001 50,000 NTD, while 23\% earn 50,001 70,000 NTD. As for average visit frequency, most respondents visit Taichung every six months or less $(41.6 \%$ ), while $37 \%$ of respondents travel to Taichung once a year.

\subsection{Reliability and Validity Analysis of the Formal Survey}

Upon completion of the formal questionnaire survey, the researcher conducted a reliability and validity analysis 
for all measurement dimensions to guarantee the reliability of the questionnaire. The reliability and validity of the questionnaire were assessed through Cronbach's $\alpha$ values and a factor analysis (as shown in Table 1). Nunnally (1978) suggests that Cronbach's $\alpha$ value greater than 0.7 indicate high internal consistency and reliability, while Kerlinger (1978) argues that item-to-total correlation coefficients must exceed a value of 0.5 . The results clearly indicate that Cronbach's $\alpha$ and correlation coefficient values met the required standards, which in turn signals an excellent overall reliability of the questionnaire.

The convergent validity of the questionnaire was determined through an Exploratory Factor Analysis (EFA). Kaiser (1958) proposes that the eigenvalues of extracted factors should exceed 1, the factor loadings of the variables in each dimension exceed 0.5 , and the cumulative explained variances are greater than 0.5 . The results indicate that the values for each dimension exceed the required standards. The questionnaire therefore exhibits excellent convergent validity.

In addition, the required standards for the Composite Reliability (CR) and Average Variance Extracted (AVE) values of the latent variables are $>0.6$ and $>0.5$, respectively (Fornell \& Larcker, 1981). The CR values for all dimensions and factors of this study range between 0.8871 and 0.9666 . The composite reliability is therefore acceptable, which indicates that the dimensions of this study have excellent internal consistency. The AVE values range between 0.6629 and 0.9033 , which signals that the convergent validity is acceptable. In other words, all measurement items of the dimensions are characterized by a high level of consistency.

Table 1. Reliability and validity analysis for formal survey

\begin{tabular}{|c|c|c|c|c|c|c|c|}
\hline Variable & $\begin{array}{l}\text { Item to } \\
\text { total } \\
\text { correlation }\end{array}$ & $\begin{array}{l}\text { Factor } \\
\text { loading }\end{array}$ & Eigenvalues & $\begin{array}{l}\text { Cumulative } \\
\text { explained } \\
\text { variance } \%\end{array}$ & $\begin{array}{l}\text { Cronbach } \\
\alpha\end{array}$ & $\begin{array}{l}\text { Composite } \\
\text { reliability } \\
(\mathrm{CR})\end{array}$ & $\begin{array}{l}\text { Average } \\
\text { extracted } \\
\text { variance } \\
\text { (AVE) }\end{array}$ \\
\hline \multicolumn{8}{|l|}{ City Social Responsibility } \\
\hline Economic responsibility & & & 3.365 & 84.123 & .937 & 0.9549 & 0.841 \\
\hline $\begin{array}{l}\text { Taichung City Government actively } \\
\text { develops the city's unique features }\end{array}$ & .865 & .926 & & & & & \\
\hline $\begin{array}{l}\text { Taichung City Government actively } \\
\text { promotes the local economy }\end{array}$ & .869 & .925 & & & & & \\
\hline $\begin{array}{l}\text { Taichung City Government has established } \\
\text { an excellent public transportation system }\end{array}$ & .827 & .903 & & & & & \\
\hline $\begin{array}{l}\text { Taichung City Government has established } \\
\text { excellent information communication } \\
\text { channels }\end{array}$ & .843 & .914 & & & & & \\
\hline Legal responsibility & & & 3.354 & 83.845 & .936 & 0.9541 & 0.8387 \\
\hline $\begin{array}{l}\text { Taichung City Government actively } \\
\text { implements urban quality promotion and } \\
\text { planning }\end{array}$ & .820 & .899 & & & & & \\
\hline $\begin{array}{l}\text { Taichung City Government provides } \\
\text { convenient services for citizens }\end{array}$ & .867 & .925 & & & & & \\
\hline $\begin{array}{l}\text { Taichung City Government actively } \\
\text { enforces environmental laws and } \\
\text { regulations }\end{array}$ & .864 & .927 & & & & & \\
\hline $\begin{array}{l}\text { Taichung City Government actively } \\
\text { promotes traffic laws and regulations }\end{array}$ & .837 & .912 & & & & & \\
\hline Ethical responsibility & & & 3.317 & 82.929 & .931 & 0.9511 & 0.8296 \\
\hline $\begin{array}{l}\text { Taichung City Government shows genuine } \\
\text { concern for living standards of its people }\end{array}$ & .877 & .935 & & & & & \\
\hline $\begin{array}{l}\text { Taichung City Government provides } \\
\text { employment opportunities for city } \\
\text { residents }\end{array}$ & .877 & .934 & & & & & \\
\hline $\begin{array}{l}\text { Taichung City Government actively } \\
\text { promotes energy conservation and the } \\
\text { creation of a low carbon city }\end{array}$ & .812 & .894 & & & & & \\
\hline $\begin{array}{l}\text { Taichung City Government is actively } \\
\text { committed to protecting the safety of city } \\
\text { residents }\end{array}$ & .790 & .879 & & & & & \\
\hline
\end{tabular}




\begin{tabular}{|c|c|c|c|c|c|c|c|}
\hline \multicolumn{3}{|l|}{ Philanthropic responsibility } & \multirow[t]{5}{*}{3.515} & \multirow[t]{5}{*}{87.874} & \multirow[t]{5}{*}{.954} & \multirow[t]{5}{*}{0.9666} & \multirow[t]{5}{*}{0.8786} \\
\hline $\begin{array}{l}\text { Taichung City Government shows } \\
\text { excellent performance in the field of } \\
\text { philanthropic and public welfare activities }\end{array}$ & .893 & .941 & & & & & \\
\hline $\begin{array}{l}\text { Taichung City Government shows great } \\
\text { concern for disadvantaged groups }\end{array}$ & .919 & .955 & & & & & \\
\hline $\begin{array}{l}\text { Taichung City Government makes } \\
\text { donations to charity organizations }\end{array}$ & .887 & .938 & & & & & \\
\hline $\begin{array}{l}\text { Taichung City Government fully supports } \\
\text { local cultural and sports activities }\end{array}$ & .851 & .915 & & & & & \\
\hline \multicolumn{8}{|l|}{ City Marketing Strategy } \\
\hline Image marketing & & & \multirow[t]{5}{*}{2.935} & \multirow[t]{5}{*}{73.376} & \multirow[t]{5}{*}{.870} & \multirow[t]{5}{*}{0.9149} & \multirow[t]{5}{*}{0.7339} \\
\hline $\begin{array}{l}\text { Taichung City Government has an } \\
\text { excellent image }\end{array}$ & .450 & .607 & & & & & \\
\hline $\begin{array}{l}\text { Taichung City Image leaves a deep } \\
\text { impression on people }\end{array}$ & .829 & .917 & & & & & \\
\hline $\begin{array}{l}\text { Taichung City Government has unique } \\
\text { characteristics which are different from } \\
\text { other cities }\end{array}$ & .860 & .936 & & & & & \\
\hline $\begin{array}{l}\text { Taichung City Government constantly } \\
\text { releases brand-new city image } \\
\text { advertisements }\end{array}$ & .839 & .922 & & & & & \\
\hline Attraction marketing & & & \multirow[t]{7}{*}{4.301} & \multirow[t]{7}{*}{71.677} & \multirow[t]{7}{*}{.921} & \multirow[t]{7}{*}{0.9382} & \multirow[t]{7}{*}{0.7168} \\
\hline $\begin{array}{l}\text { Taichung City organizes festival activities } \\
\text { to attract visitors }\end{array}$ & .775 & .848 & & & & & \\
\hline $\begin{array}{l}\text { Taichung City has attractive culinary } \\
\text { specialties }\end{array}$ & .749 & .824 & & & & & \\
\hline Taichung City has attractive folk customs & .786 & .859 & & & & & \\
\hline $\begin{array}{l}\text { Taichung City Government has an } \\
\text { attractive life quality }\end{array}$ & .795 & .867 & & & & & \\
\hline Taichung City has attractive tourist spots & .787 & .857 & & & & & \\
\hline $\begin{array}{l}\text { Taichung City Government has attractive } \\
\text { natural landscapes }\end{array}$ & .742 & .824 & & & & & \\
\hline \multicolumn{3}{|l|}{ Infrastructure marketing } & \multirow[t]{5}{*}{2.881} & \multirow[t]{5}{*}{72.019} & \multirow[t]{5}{*}{.870} & \multirow[t]{5}{*}{0.9113} & \multirow[t]{5}{*}{0.7202} \\
\hline $\begin{array}{l}\text { Taichung City offers an excellent bus } \\
\text { discount plan }\end{array}$ & .694 & .837 & & & & & \\
\hline $\begin{array}{l}\text { Taichung City has excellent public } \\
\text { infrastructure facilities }\end{array}$ & .821 & .912 & & & & & \\
\hline $\begin{array}{l}\text { Taichung City has excellent urban } \\
\text { planning }\end{array}$ & .708 & .838 & & & & & \\
\hline $\begin{array}{l}\text { Taichung City Government has excellent } \\
\text { Internet services }\end{array}$ & .665 & .804 & & & & & \\
\hline \multicolumn{3}{|l|}{ People marketing } & \multirow[t]{4}{*}{2.482} & \multirow[t]{4}{*}{82.724} & \multirow[t]{4}{*}{.895} & \multirow[t]{4}{*}{0.9349} & 0.8274 \\
\hline $\begin{array}{l}\text { Taichung City residents are friendly and } \\
\text { warm }\end{array}$ & .801 & .915 & & & & & \\
\hline $\begin{array}{l}\text { Taichung City residents are willing to } \\
\text { share information about local tourist spots }\end{array}$ & .840 & .933 & & & & & \\
\hline $\begin{array}{l}\text { Taichung City residents have an attractive } \\
\text { pace of life }\end{array}$ & .741 & .880 & & & & & \\
\hline City Image & & & & & & & \\
\hline Landscape construction & & & 2.580 & 85.989 & .918 & 0.9483 & 0.8595 \\
\hline $\begin{array}{l}\text { Taichung City has impressive and unique } \\
\text { temples }\end{array}$ & .826 & .924 & & & & & \\
\hline $\begin{array}{l}\text { Taichung City has impressive historical } \\
\text { sites }\end{array}$ & .873 & .946 & & & & & \\
\hline $\begin{array}{l}\text { Taichung City has impressive and unique } \\
\text { architectural features }\end{array}$ & .803 & .911 & & & & & \\
\hline Infrastructure & & & 2.383 & 79.442 & .869 & 0.9205 & 0.7948 \\
\hline $\begin{array}{l}\text { Taichung City has very convenient } \\
\text { transportation infrastructure }\end{array}$ & .772 & .922 & & & & & \\
\hline
\end{tabular}




\begin{tabular}{|c|c|c|c|c|c|c|c|}
\hline $\begin{array}{l}\text { Taichung City Government has very } \\
\text { convenient public infrastructure }\end{array}$ & .814 & .938 & & & & & \\
\hline $\begin{array}{l}\text { Taichung City road maintenance is } \\
\text { excellent }\end{array}$ & .624 & .809 & & & & & \\
\hline Local customs and conditions & & & 2.653 & 66.321 & .830 & 0.8871 & 0.6629 \\
\hline $\begin{array}{l}\text { Taichung City has an excellent } \\
\text { geographical location }\end{array}$ & .644 & .827 & & & & & \\
\hline Taichung City has a pleasant climate & .683 & .848 & & & & & \\
\hline $\begin{array}{l}\text { Taichung City has excellent achievements } \\
\text { in environmental and ecological } \\
\text { conservation }\end{array}$ & .627 & .779 & & & & & \\
\hline $\begin{array}{l}\text { Taichung City commercial districts have a } \\
\text { unique character }\end{array}$ & .666 & .801 & & & & & \\
\hline History and culture & & & 2.573 & 85.758 & .917 & 0.9475 & 0.8576 \\
\hline Taichung City has valuable cultural relics & .829 & .925 & & & & & \\
\hline $\begin{array}{l}\text { Taichung City has complete historical and } \\
\text { cultural information }\end{array}$ & .856 & .939 & & & & & \\
\hline Taichung City has famous religious sites & .809 & .914 & & & & & \\
\hline \multicolumn{8}{|l|}{ People's Trust } \\
\hline Credibility & & & 2.408 & 80.278 & .877 & 0.9242 & 0.8027 \\
\hline $\begin{array}{l}\text { Taichung City Government has high } \\
\text { credibility }\end{array}$ & .818 & .925 & & & & & \\
\hline $\begin{array}{l}\text { Taichung City will become increasingly } \\
\text { prosperous }\end{array}$ & .720 & .873 & & & & & \\
\hline Taichung City is extremely safe & .752 & .889 & & & & & \\
\hline Benevolence & & & 2.709 & 90.298 & .946 & 0.9655 & 0.9033 \\
\hline $\begin{array}{l}\text { Taichung City Government gives priority } \\
\text { to public interests }\end{array}$ & .874 & .944 & & & & & \\
\hline $\begin{array}{l}\text { Taichung City Government makes active } \\
\text { efforts to gain an understanding of the } \\
\text { needs of city residents }\end{array}$ & .927 & .969 & & & & & \\
\hline $\begin{array}{l}\text { Taichung City Government is fully } \\
\text { committed to providing assistance for city } \\
\text { residents }\end{array}$ & .861 & .938 & & & & & \\
\hline \multicolumn{8}{|l|}{ People's Intention } \\
\hline I am willing to take a trip to Taichung & .810 & .872 & 4.807 & 80.119 & .950 & 0.9603 & 0.8013 \\
\hline $\begin{array}{l}\text { Taichung City will be my first choice for } \\
\text { my next trip }\end{array}$ & .828 & .886 & & & & & \\
\hline I intend to settle in Taichung City & .801 & .864 & & & & & \\
\hline $\begin{array}{l}\text { I am willing to recommend a trip to } \\
\text { Taichung to others }\end{array}$ & .880 & .916 & & & & & \\
\hline $\begin{array}{l}\text { I am willing to recommend residence in } \\
\text { Taichung to others }\end{array}$ & .900 & .928 & & & & & \\
\hline $\begin{array}{l}\text { I am willing to recommend the unique } \\
\text { features of Taichung to others }\end{array}$ & .864 & .903 & & & & & \\
\hline
\end{tabular}

\subsection{Confirmatory Factor Analysis}

The researcher also conducted a Confirmatory Factor Analysis (CFA) for the measurement model of the five dimensions of city social responsibility, city marketing strategy, city image, people's trust, and people's intention with AMOS software to verify the efficiency of the measurement dimensions.

Carmines \& MacIver (1981) state that the Suitability Index of models must meet the requirement of chi-square to DF ratio $\left(\chi^{2} / \mathrm{df}\right) \leqq 3$ and Root mean square residual (RMR) and Root mean square error of approximation (RMSEA) should be less than 0.5. Normed fit index (NFI) and Comparative fit index (CFI) should be greater than 0.9 (Bagozzi \& Yi, 1988; Joreskog \& Sorbom, 1989). Goodness of fit index (GFI) and Adjusted goodness of fit index (AGFI) should be greater than 0.8 (Sharma, 1996 and Segars \& Grover, 1993). The Suitability Index for the measurement model of this study is composed of the following values: $\chi^{2} / \mathrm{df}$ of 1.892 , GFI of 0.747 , AGFI of 0.703 , NFI of 0.861 , RFI of 0.842 , CFI of 0.929, RMSEA of 0.040 , and RMR of 0.086 . It is therefore evident that the suitability of the measurement model falls within an acceptable range and that the model is highly 
suitable. This also indicates that the measurement index has construct validity and measurement efficiency.

\subsection{Competing Model Comparative Analysis}

The researcher divided the 548 valid questionnaires into two groups based on travel frequency. Respondents with a travel frequency of at least 1 trip per six months were classified into the high-frequency group (a total of 230 questionnaires), while respondents with a travel frequency of less than one trip per six months were assigned to the low-frequency group (total of 318 questionnaires). A competing model analysis was then conducted for the two groups with AMOS software to determine whether or not significant differences exist between the two groups as far as the correlations between the different dimensions are concerned. The suitability of the competing model is shown in Table 2 with the following index: $\chi^{2} / \mathrm{df}$ of 1.892 , RMR of 0.086 , GFI of 0.747 , AGFI of 0.703 , NFI of 0.861 , RFI of 0.842 , CFI of 0.929 , and RMSEA of 0.040 . These values meet the criteria of a good model, which indicates that the competing model of this study is highly suitable and acceptable. The following results can be obtained from the standardized parameter estimates of the competing model:

(1) There is a significant positive correlation between city social responsibility and people's trust and there is no significant difference between the high- and low-frequency groups as far as this correlation is concerned $(t=1.299)$. This clearly indicates that people's trust in both groups is affected by the fulfillment of city social responsibility. $\mathrm{H} 1$ is therefore supported.

(2) The high-frequency and low-frequency groups exhibit significant differences as far as the correlation between social responsibility and city image is concerned $(t=-2.269)$. Based on a comparison of influence coefficients, it is evident that a strong positive correlation for this path only exists for the high-frequency group. This clearly indicates that fulfillment of social responsibility tends to generate a positive perception of city image in the high-frequency group. This is not true for the low-frequency group. This may be related to the fact that the low-frequency group visits Taichung less frequency and is therefore not aware of which social responsibilities have been fulfilled in Taichung. $\mathrm{H} 2$ is therefore only supported for the high-frequency group.

(3) There is no significant difference between the high-frequency and low-frequency groups as far as the correlation between social responsibility and people's intention is concerned $(t=-0.329)$. People's intention in both groups is not affected by fulfillment of social responsibility, which in turn indicates that city social responsibility has no direct impact on people's intention. H3 is therefore not corroborated.

(4) There is no significant difference between the high-frequency and low-frequency groups as far as the correlation between city marketing strategy and people's trust is concerned $(t=-1.334)$. City marketing has a significant negative impact on trust in the city in the low-frequency group. H4 is therefore not confirmed. This shows that city marketing strategies don't increase people's trust which deserves further attention.

(5) Both groups show a positive correlation between city marketing strategy and city image, but there is a significant difference in the strength of the correlation $(t=2.341)$. The correlation for this path is stronger in the low-frequency group. This indicates that the perception of city image in the low-frequency group is strongly affected by city marketing strategies. H5 is therefore supported.

(6) Both groups show a positive correlation between city marketing strategy and people's intention. There is no significant difference in the strength of the correlation $(\mathrm{t}=0.199)$. This indicates that people's intention in groups with different travel frequencies is positively affected by city marketing strategies. H6 is therefore corroborated.

(7) Both groups show a positive correlation between city image and people's trust. There is no significant difference in the strength of the correlation $(\mathrm{t}=0.863)$. The influence coefficient values for both groups are high. This indicates that people's trust in cities in groups with different travel frequencies is strongly affected by city image. $\mathrm{H} 7$ is therefore confirmed.

(8) There is a significant difference between the high-frequency and low-frequency groups as far as the correlation between people's trust and people's intention is concerned $(t=-2.256)$. The correlation for this path is stronger in the high-frequency group. This indicates that the high-frequency group tends to show a higher intention to visit the cities if high levels of trust are present. This is not true for the low-frequency group. H8 is therefore supported for the high-frequency group.

(9) Both the low- frequency and high-frequency groups did not show a significant correlation between city image and people's intention. Although the low-frequency group shows a stronger correlation for this path than the high-frequency group, $\mathrm{H} 9$ is not confirmed due to the fact that the correlation is insignificant.

To sum up, the high frequency and low-frequency groups show significant differences in the intensity of four correlations. This indicates that different travel frequencies have a considerable impact on the correlation 
intensities for certain paths. H10 is therefore partially supported. This also shows that high or low travel frequencies lead to differences in the correlation structure, which represents another important finding of this study.

Table 2. The competing model analysis for different travel frequencies groups

\begin{tabular}{|c|c|c|c|c|c|c|c|c|c|}
\hline \multirow{3}{*}{\multicolumn{4}{|c|}{ Mode path }} & \multicolumn{4}{|c|}{ Standardized Regression Weights } & \multicolumn{2}{|c|}{$\mathrm{T}$ test results } \\
\hline & & & & \multirow{2}{*}{\multicolumn{2}{|c|}{$\begin{array}{l}\begin{array}{l}\text { highly } \\
\text { frequent } \\
\text { group }\end{array} \\
230\end{array}$}} & \multicolumn{2}{|l|}{$\begin{array}{l}\text { infrequent } \\
\text { group }\end{array}$} & \multirow{2}{*}{\multicolumn{2}{|c|}{$\begin{array}{l}\text { highly } \\
\text { v.s } \\
\text { infrequent }\end{array}$}} \\
\hline & & & & & & \multicolumn{2}{|l|}{318} & & \\
\hline \multicolumn{4}{|c|}{ H1: City Social Responsibility $\rightarrow$ Peoples' Trust } & $0.258 * *$ & & \multicolumn{2}{|l|}{$0.398 * * *$} & \multicolumn{2}{|l|}{1.299} \\
\hline \multicolumn{4}{|c|}{ H2: City Social Responsibility $\rightarrow$ City Image } & $0.301 * *$ & & \multicolumn{2}{|l|}{-0.022} & \multicolumn{2}{|l|}{$-2.269 * *$} \\
\hline \multicolumn{4}{|c|}{ H3: City Social Responsibility $\rightarrow$ Peoples' Intention } & 0.086 & & \multicolumn{2}{|l|}{0.034} & \multicolumn{2}{|l|}{-0.329} \\
\hline \multicolumn{4}{|c|}{ H4: City Marketing Strategy $\rightarrow$ Peoples' Trust } & -0.132 & & \multicolumn{2}{|l|}{$-0.329 * *$} & \multicolumn{2}{|l|}{-1.334} \\
\hline \multicolumn{4}{|c|}{ H5: City Marketing Strategy $\rightarrow$ City Image } & $0.527 * * *$ & & \multicolumn{2}{|l|}{$0.832 * * *$} & \multicolumn{2}{|l|}{$2.341 * *$} \\
\hline H6: City N & arketin & $y \rightarrow 1$ & ples' Intention & $0.411 * * *$ & & \multicolumn{2}{|l|}{$0.395 * *$} & \multicolumn{2}{|l|}{0.199} \\
\hline \multicolumn{4}{|c|}{ H7: City Image $\rightarrow$ Peoples' Trust } & $0.817 * * *$ & & \multicolumn{2}{|l|}{$0.955 * * *$} & \multicolumn{2}{|l|}{0.863} \\
\hline \multicolumn{4}{|c|}{ H8: Peoples' Trust $\rightarrow$ Peoples' Intention } & $0.634 * * *$ & & \multirow{2}{*}{\multicolumn{2}{|c|}{$\begin{array}{l}-0.018 \\
0.317\end{array}$}} & \multicolumn{2}{|l|}{$-2.256 * *$} \\
\hline \multicolumn{4}{|c|}{ H9: City Image $\rightarrow$ Peoples' Intention } & -0.291 & & & & \multicolumn{2}{|l|}{$2.15 * *$} \\
\hline \multicolumn{10}{|l|}{ Model Fit } \\
\hline$x^{2}$ & d.f. & $\mathrm{P}$ & $x^{2} /$ d.f. & GFI & AGFI & NFI & RFI & $\mathrm{CFI}$ & RMSEA \\
\hline 5502.418 & 2908 & .000 & 1.892 & .747 & .703 & .861 & .842 & .929 & .040 \\
\hline
\end{tabular}

*P $<0.05 ; * * \mathrm{P}<0.01 ; * * * \mathrm{P}<0.001$

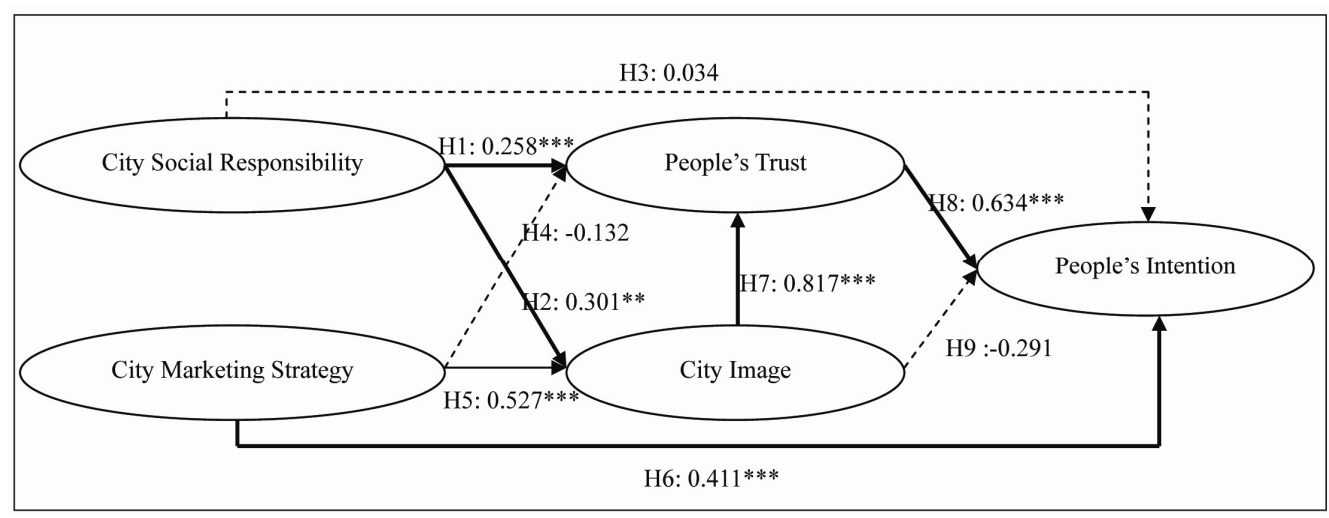

Figure 1. Highly frequent group

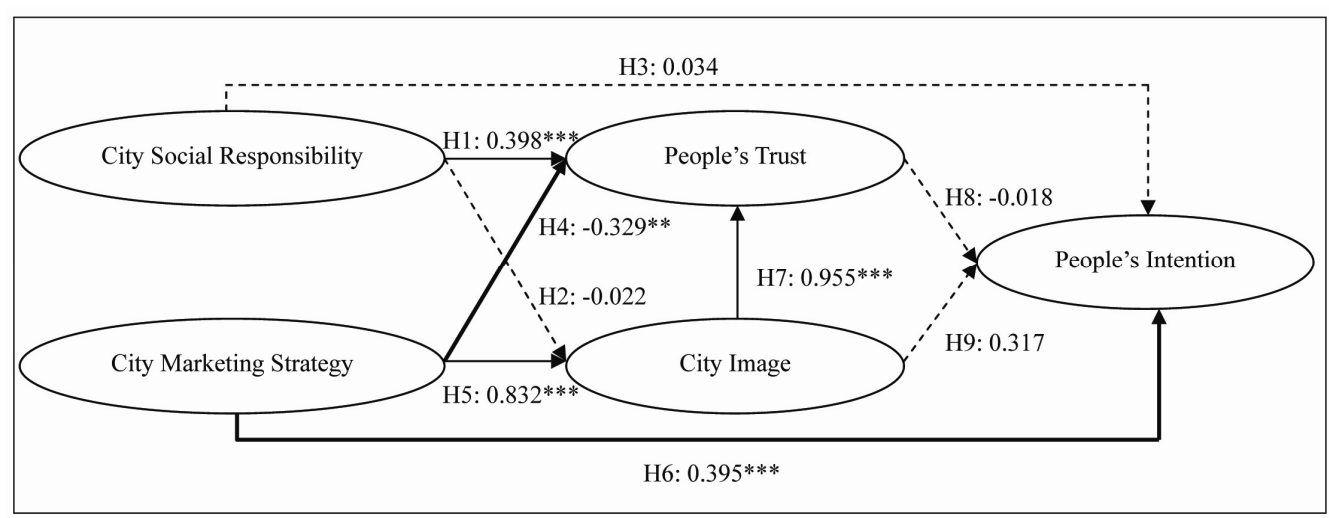

Figure 2. Infrequent group 


\section{Conclusions and Recommendations}

\subsection{Conclusions and Implications for Management}

This study explores the impact of city social responsibility and marketing strategy on city image, people's trust, and people's intention. Relationship models were established for different dimensions based on empirical analyses. Efficient measurement variables were identified to provide academic and business circles with important framework concepts and research tools with high academic and practical value. The following conclusions can be drawn based on the research results:

The fulfillment of social responsibilities by a city leads to increased trust and a more positive image perception on the part of the high-frequency group, which in turn results in a higher intention to visit or settle in said city, while the implementation of city marketing strategies leads to a more positive image perception and a higher intention to visit or settle in said city but has no positive effect on people's trust in cities. This shows that the high-frequency group tends to exhibit a stronger sense of trust if the city fulfills its social responsibility. Implementation of attractive marketing strategies by cities, on the other hand, directly increases the intention of citizens to visit or settle in said city. These two independent variables are therefore important influence variables. In conclusion, cities can establish positive city images and increase the trust of high-frequency groups by meeting their social responsibility, which in turn indirectly increases their intention to visit or settle in the city. In addition, it is also of key importance to increase people's intention through the implementation of marketing strategies.

The fulfillment of social responsibilities by a city also leads to increased trust in the city on the part of the low-frequency group. Image perceptions and visit intention, however, remain unaffected. The implementation of city marketing strategies, on the other hand, directly increases the intention of citizens to visit or settle in said city. The impact of marketing strategy on people's intention is the only main path for this group. This clearly shows that the low-frequency group tends to exhibit a higher intention to visit or settle in a city due to the implementation of marketing strategies. The planning of marketing strategies therefore has to meet the needs of this group (as shown in Figure 2)

A comparison of the high-frequency and low-frequency groups shows that significant differences exist in the intensity of four correlations (fulfillment of social responsibility-city image, implementation of city marketing strategy-city image, people's trust-people's intention, and city image-people's intention). Different strategies should therefore be proposed for different groups.

An analysis of two groups with different travel frequencies shows certain differences and similarities between these two groups. The researcher therefore proposes the following management directions and recommendations:

As far as the high-frequency group is concerned, the fulfillment of social responsibilities by a city leads to increased trust in the city and a more positive image perception, which in turn directly affects the intention to visit or settle in said city. Cities should therefore provide more information about their

Implementation of social responsibility to raise the awareness of the general public regarding their efforts and achievements in this field can positively affect the perceptions and intentions of the general public. For instance, the establishment of better information communication channels gives the general public access to real-time information. The organization of local cultural activities such as exhibitions and competitions attracts visitor crowds. Another important aspect is the increased participation in philanthropic and public welfare activities. In addition, the implementation of marketing strategies by cities has a significant positive impact on city image and people's intention. This indicates that the implementation of attractive marketing strategies by cities generates a more positive image perception and a higher intention to visit these cities on the part of the general public. A positive city image also leads to a stronger sense of trust among citizens. Cities should therefore publicize more brand-new city image advertisements and organize attractive festival activities to create a city image and thereby increase the sense of trust of citizens as well as visits by high-frequency groups and the intention to settle or make investments.

As far as the low-frequency group is concerned, city marketing strategy has a significant impact on the travel intention of the general public, which indicates that the implementation of attractive city marketing strategies increases the intention of citizens to visit or settle in a city. The city can therefore market local culinary specialties, folk customs, and life quality in Taichung City and establish a positive city image with the goal of generating a more positive perception by the general public and increase the intention to visit or settle in that city. However, the implementation of city marketing strategy has a significant negative impact on people's trust. For instance, Taichung City actively markets the Bus Rapid Transit (BRT) system, but the rushed launch of the 
system has generated problems, which in turn has created a negative impression in the mind of the general public. Taichung City Government should therefore focus on the needs of the general public before implementing marketing initiatives and pay attention to the quality of implementation to achieve the desired results and increase the trust of the general public. This study therefore recommends that the city government should ensure that marketing strategies meet the needs of citizens and that the general public is aware of government efforts and the benefits of relevant strategies. The city should also attempt to gain a full understanding of citizen needs and provide assistance to generate a sense of trust in the city and increase the intention to visit or settle in the city.

\subsection{Limitations and Future Recommendations}

This study focuses on Taichung City. However, conditions and methods of implementation of social responsibility, city marketing, and city image in Taichung are different from other cities. It is therefore recommended to expand the research scope to other cities and regions in the future to verify the suitability of the conceptual model of this study. In addition, different groups may have different perceptions and attention levels as far as city social responsibility and city marketing are concerned. This study uses travel frequency as the sole segmentation criterion. Future studies should therefore use different segmentation variables for classification and comparative analysis to show potential differences for the correlation model employed for this study, facilitate follow-up strategic planning, and further increase the value of this research.

This study does not consider that the relationships between city social responsibility and marketing strategies, because the major purpose of this paper is to compare the influence degree between these two factors. However the relationships between these two factors maybe existed that should be explored in future research. On the other hand, city image, people's trust, and people's intention, mostly depend on the specific characteristics and quality of the city social responsibility and marketing strategies that also need a further study.

\section{References}

Armstrong, G., \& Kolter, P. (2000). Marketing: an introduction (5th ed.). Englewood Cliff, NJ: Prentice Hall.

Bagozzi, R. P., \& Yi, Y. (1988). On the evaluation of structure equations models. Journal of the Academy of Marketing Science, 16(1), 74-94. http://dx.doi.org/10.1007/BF02723327

Beléndel Río, A., Vazquez, R., \& Iglesias, V. (2001). The effects of brand associations on consumer response. Journal of consumer marketing, 18(5), 410-425. http://dx.doi.org/10.1108/07363760110398808

Bennett, R., \& Koudelova, R. (2001). Image selection and the marketing of downtown areas in London and New York. International Journal of Public Sector Management, 14(3), 205-220. http://dx.doi.org/10.1108/09513550110390855

Boulding, W., Kalra, A., Staelin, R., \& Zeithaml, V. A. (1993). A dynamic process model of service quality: from expectation to behavioral intentions. Journal of Marketing Research, 30, 7-27. http://dx.doi.org/10.2307/3172510

Brammer, S., \& Millington, A. (2005). Corporate reputation and philanthropy: an empirical analysis. Journal of Business Ethics, 61(1), 29-44. http://dx.doi.org/10.1007/s10551-005-7443-4

Burnett, J., \& Moriarty, S. E. (1998). Introduction to marketing communication: an integrated approach. NJ: Prentice Hall.

Carmines, E. G., \& McIver, J. P. (1981). Analyzing models with unobserved variables: Analysis of covariance structures. Social Measurement: Current Issues, 65-115.

Carroll, A. B. (1991). The pyramid of corporate social responsibility: toward the moral management of $\begin{array}{lllll}\text { organizational } & \text { stakeholders. } & \text { Business } & \text { Horizons, } & 34(4),\end{array}$ http://dx.doi.org/10.1016/0007-6813(91)90005-G

Chaudhuri, A., \& Holbrook, M. B. (2001). The chain of effects from brand trust and brand affect to brand performance: the role of brand loyalty. Journal of marketing, 65(2), 81-93. http://dx.doi.org/10.1509/jmkg.65.2.81.18255

Chien, P. M., Cornwell, T. B., \& Pappu, R. (2011). Sponsorship portfolio as a brand-image creation strategy. Journal of Business Research, 64(2), 142-149. http://dx.doi.org/10.1016/j.jbusres.2010.02.010

Cronin, J. J., Brady, M. K., \& Hult, G. T. M. (2000). Assessing the effects of quality, value, and customer satisfaction on consumer behavioral intentions in service environments. Journal of retailing, 76(2), $193-218$. http://dx.doi.org/10.1016/S0022-4359(00)00028-2 
Crosby, L. A., Evans, K. R., \& Cowles, D. (1990). Relationship quality in services selling: an interpersonal influence perspective. The Journal of Marketing, 54(3), 68-81. http://dx.doi.org/10.2307/1251817

Davis, K., \& Blomstrom, R. L. (1975). Business, society, and environment: social power and social response (2nd ed.). New York: McGraw-Hill.

Doney, P. M., \& Canon, J. P. (1997). An examination of the nature of trust in buyer-seller relationship. Journal of Marketing, 61(2), 35-51. http://dx.doi.org/10.2307/1251829

Fornell, C., \& Larcker, D. F. (1981). Structural equation models with unobservable variables and measurement error: Algebra and statistics. Journal of marketing research, 18(3), 382-388. http://dx.doi.org/10.2307/3150980

Ganesan, S. (1994). Determinants of long-term orientation in buyer-seller relationships. Journal of Marketing, 58(2), 1-19. http://dx.doi.org/10.2307/1252265

Garbarino, E., \& Johnson, M. S. (1999).The different roles of satisfaction, trust, and commitment in customer relationships. Journal of Marketing, 63(2), 70-87. http://dx.doi.org/10.2307/1251946

Gefen, D. (2002). Reflections on the dimensions of trust and trustworthiness among online consumers. Acmsigmis Database, 33(3), 38-53. http://dx.doi.org/10.1145/569905.569910

Gobé, M. (2002).Citizen Brand: 10 Commandments for Transforming Brand Culture in a Consumer Democracy. New York: Allworth Press.

Gronholdt, L., Martensen, A. \& Kristensen, K. (2000). The relationship between customer satisfaction and Loyalty: cross-industry different. Total Quality Management, 11(4-6), 509-514. http://dx.doi.org/10.1080/09544120050007823

Hennig-Thurau, T., \& Klee, A. (1997). The impact of customer satisfaction and relationship quality on customer retention: A critical reassessment and model development. Psychology \& Marketing, 14(8), 737-764. http://dx.doi.org/10.1002/(SICI)1520-6793(199712)14:8<737::AID-MAR2>3.3.CO;2-Z

Hennig-Thurau, T., Gwinner, K. P., \& Gremler, D. D. (2002). Understanding relationship marketing outcomes. Journal of Service Research, 4(3), 230-247. http://dx.doi.org/10.1177/1094670502004003006

Joreskog, K. G., \& Sorbom, D. (1989). LISREL 7 Use’s Reference Guide. (Lslfed.). Chicago: Scientific Software.

Kaiser, H. F. (1958). Thevarimax criterion for analysis rotation in factor analysis. Psychometrika, 23(3), 187-200. http://dx.doi.org/10.1007/BF02289233

Kerlinger, F. N. (1978). Foundation of Behavioral Research. New York: McGraw-Hill.

Kotler, P., \& Armstrong, G. (2005). Principles of Marketing (11th ed.).

Kotler, P., Haider, D. H., \& Rein, I. (1993). Marketing places: attracting investment, industry and tourism to cities, states and nations. Nova Iorque: Free Press.

Krantz, M., \& Schatzl, L. (1997). Marketing the city. European Cities in Competition, 468-491.

Lichtenstein, D. R., Drumwright, M. E., \& Braig, B. M. (2004). The effect of corporate social responsibility on customer donations to corporate-supported nonprofits. Journal of Marketing, 68(4), 16-32. http://dx.doi.org/10.1509/jmkg.68.4.16.42726

Luque-Martínez, T., Barrio-García, S. D., Ibáñez-Zapata, J. Á., \&, Molina, M. Á. R. (2007). Modeling a city’s image: the case of granada. Cities, 24(5), 335-352. http://dx.doi.org/10.1016/j.cities.2007.01.010

Morgan, R. M., \& Hunt, S. D. (1994). The commitment-trust theory of relationship marketing. Journal of Marketing, 58(3), 20-38. http://dx.doi.org/10.2307/1252308

Moussavi, F., \&Evans, D. (1986). An attributional approach to measuring corporate social performance. Paper Presented at the Academy of Management Meetings. San Diego.

Murphy, L., Benckendorff, P., \& Moscardo, G. (2007). Destination brand personality: visitor perceptions of a regional tourism destination. Tourism Analysis, 12(5-6), 419-432. http://dx.doi.org/10.3727/108354207783227948

Nunnally, J. C. (1978). Psychometric Theory. New York: Mcgraw-Hill.

Paddison, R. (1993). City marketing, image reconstruction and urban regeneration. Urban Studies, 30(2), 339-350. http://dx.doi.org/10.1080/00420989320080331 
Peters, M., \& Weiermair, K. (2000). Tourist attractions and attracted tourist: How to satisfy today's fickle tourist clientel. The Journal of Tourism Studies, 11(2), 22-29.

Pike, S., \& Ryan, C. (2004). Destination positioning analysis through a comparison of cognitive, affective, and conative perceptions. Journal of Travel Research, 42(2), 333-342. http://dx.doi.org/10.1177/0047287504263029

Ranaweera, C., \& Prabhu, J. (2003). The influence of satisfaction, trust and switching barriers on customer retention in a continuous purchasing setting. International Journal of Service Industry Management, 14(4), 374-395. http://dx.doi.org/10.1108/09564230310489231

Richardson, P. S., Dick, A. S., \& Jain, A. K. (1994). Extrinsic and extrinsic cue effect on perceptions of store brand quality. Journal of Marketing Research, 58(4), 28-36. http://dx.doi.org/10.2307/1251914

Roche, M. (1994). Mega-events and urban policy. Annals of Tourism Research, 21(1), 1-19. http://dx.doi.org/10.1016/0160-7383(94)90002-7

Scharl, A., Dickinger, A., \& Weichselbraun, A. (2008). Analyzing news media coverage to acquire and structure tourism knowledge. Information Technology \& Tourism, 10(1), 3. http://dx.doi.org/10.3727/109830508785059039

Schmitt, B. H. (1999). Experiential Marketing: How to Get Customer to Sense, Feel, Think, Act, Relate to Your Company and Brands. New York: Free Press.

Segars, A. H., \& Grover, V. (1993). Re-examining perceived ease of use and usefulness: a confirmatory factor analysis. MIS Quarterly, 17(4), 517-522. http://dx.doi.org/10.2307/249590

Sen, S., \& Bhattacharya, C. B. (2001). Does doing good always lead to doing better? consumer reactions to corporate social responsibility. Journal of Marketing Research, 38(2), 225-243. http://dx.doi.org/10.1509/jmkr.38.2.225.18838

Sen, S., Bhattacharya, C. B., \& Korschun, D. (2006). The role of corporate social responsibility in strengthening multiple stakeholder relationships: a field experiment. Journal of the Academy of Marketing Science, 34(2), 158-166. http://dx.doi.org/10.1177/0092070305284978

Sexty, R. W. (2011). Canadian business and society: ethics \&responsibilities. Mcgraw-hillryerson.

Sharma, S. (1996). Applied multivariate techniques (1st ed.). New York: Wiley.

Sirdeshmukh, D., Singh, J., \& Sabol, B. (2002). Consumer trust, value, and loyalty in relational exchanges. The Journal of Marketing, 66(1), 15-37. http://dx.doi.org/10.1509/jmkg.66.1.15.18449

Smeltzer, L. R. (1997). The neaning and origin of trust in buyer - supplier relationships. Journal of Supply Chain Management, 33(4), 40-48. http://dx.doi.org/10.1111/j.1745-493X.1997.tb00024.x

Tian, Z., Wang, R., \& Yang, W. (2011). Consumer responses to corporate social responsibility in China. Journal of Business Ethics, 101(2), 197-212. http://dx.doi.org/10.1007/s10551-010-0716-6

$\mathrm{Wu}, \mathrm{S}$. I., \& Lin, T. R. (2014). The influence of relational bonds and innovative marketing on consumer perceptrion-a study of theme parks. Journal of Management and Strategy, 5(4), 54-67. http://dx.doi.org/10.5430/jms.v5n4p54

Wu, S. I., \& Zheng, Y. H. (2014). The influence of tourism image and activities appeal on touristloyalty - astudy of tainancity in Taiwan. Journal of Management and Strategy, 5(4), 121-135. http://dx.doi.org/10.5430/jms.v5n4p121

Zairi, M., \& Peters, J. (2002). The impact of social responsibility on business performance. Managerial Auditing Journal, 17(4), 174-178. http://dx.doi.org/10.1108/02686900210424312

\section{Copyrights}

Copyright for this article is retained by the author(s), with first publication rights granted to the journal.

This is an open-access article distributed under the terms and conditions of the Creative Commons Attribution license (http://creativecommons.org/licenses/by/3.0/). 